of Commons, said that these issues are unfortunately not likely to catch the imagination of the public, but that he hoped to submit a short motion to the next conference which would be based on recommendations from a recent meeting on the proper use of scientific manpower. But, like the Liberals, delegates to the Labour Party Conference will not find themselves overburdened with science and technology issues. The major debates will almost certainly be concerncd with economic policy and trade union legislation, but the motions on education and the National Health Service will affect some areas of science indirectly.

In contrast with the Liboral motion on education, those submitted to the Labour conference are surprisingly dull and are mainly concerned with speeding up the process of changing to comprehensive education. The Socialist Education Association is calling for a single public examination at sixteen, the abolition of all private education and the mandatory provision of nursery education by local education authorities. Other motions call for a review of the current concept of examinations as a means of assessment and four term years in higher and further education. Prescrip. tion charges will doubtless come under attack if a composite motion on the health service is debated, but more sweeping changes are likely to be proposed in motions calling for the nationalization of the drug industry.

\section{TRADES UNIONS}

\section{Science and the TUC}

Predictably, the Trades Union Congress held in Portsmouth earlier this month was dominated by debates on government policy in the industrial sphere, and little time was spent on matters having a direct bearing on science and technology. But many matters discussed could influence the conduct of research and development indirectly. Thus there was a call for a policy for mergers laying down a "code of action" for industrial takeovers; acceptance of that part of the report of the General Council of the IUC concerned with Britain's technological progress, drug industry profits and the National Health Scrvice, and the European Economic Community.

The TUC does concern itself quite extensively with matters bearing on science and technology, however; the report of the General Council to Congress included paragraphs on Britain's technological progress, European technological cooperation, pressure vessels, carbon fibres and the Social Sciences Research Council. The fact that these issues were not debated reflects popular indifference to science policy issues. But Mrs Muriel Turner of the Association of Scientific, Technological and Managerial Staffs drew attention during the congress to a paragraph in the report which was concerned with women in scientific careers. She pointed out that the number receiving scientific or technical training was negligible and urged that a campaign be started to help recruit more women into science. And this, after all, was the TUC which came out in favour of equal pay for men and women.

$\mathrm{Mr}$ Clive Jenkins, general secretary of ASSETT, proposing an amendment which called for the abandonment of Britain's efforts to join the EEC, did not concern himself with the paragraph in the General
Council's report on European Technological Cooperation but voiced several doubts on agricultural grounds about the advisability of entering the EEC. He stated that the Treasury would have to find an extra $£ 600$ million a year, and that the majority of people in Britain were not in any case in favour of entering the EEC on existing terms. Before the amendment was put to a vote which would have resulted in ignominious defeat, Mr Jenkins withdrew it.

In a motion calling for the abolition of Health Service charges, Mr Bob Edwards of the chemical workers gave as the main reason for the financial plight of the NHS the vast profits being made by the drug industry. He suggested that if the Government carried out one recommendation of the Sainsbury Committee-the abolition of branded drugs-this would recover enough money from drug profits to pay for a free health service. This motion, which was passed overwhelmingly, also called for a new system for controlling hospitals and the health service, based on trade union, professional and local government representation.

\section{AIRPORTS \\ living without Stansted}

THE British Airports Authority is still smarting from the decision of the British Government in February 1968 to throw the question of where to build a third London airport on the shoulders of a commission under Mr Justice Roskill. In its annual report for the year ending in March, the authority is at great pains to point out how the postponement of the plan for a third airport at Stansted has interfered with its forward planning. Close readers of the report may well, however, be disappointed by the authority's scant acknowledgment that the opponents of the plan to build at Stansted may have had a case. At one point, the authority suggests that this change of plan was "a result of
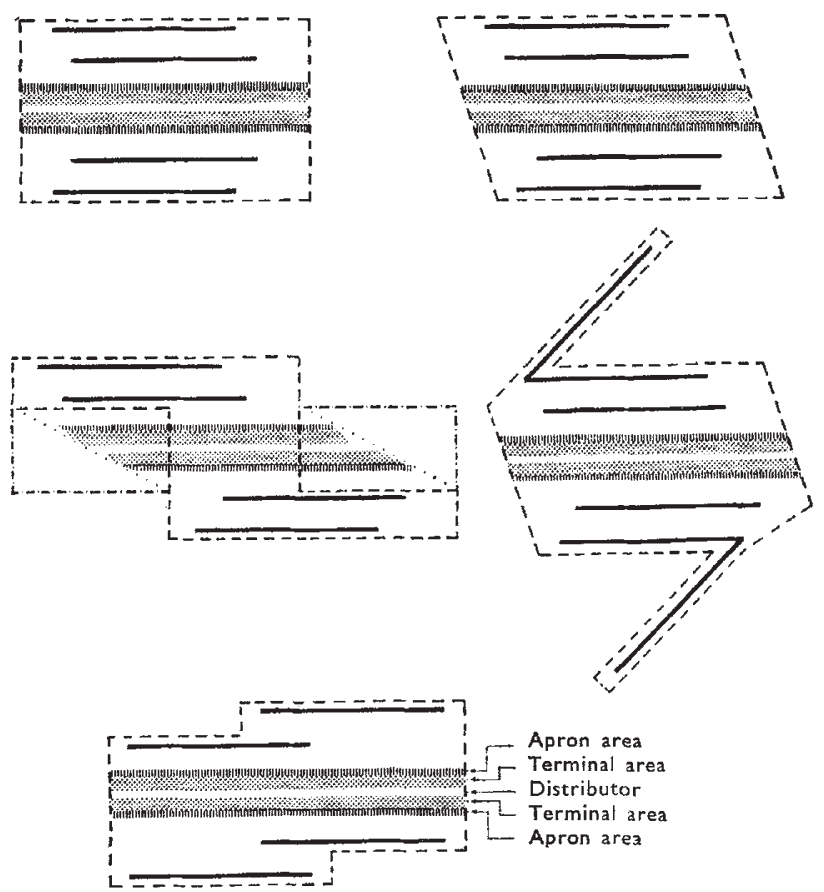

Possible alternatives for a multi-runway airport. Runway length, 14,000 feet. 